\title{
Mixotrophic nanoflagellates in coastal sediments in the western Baltic Sea
}

\author{
Stefanie Moorthi ${ }^{1,2, *}$, Ulrike-G. Berninger ${ }^{1,3}$ \\ ${ }^{1}$ Leibniz Institute of Marine Sciences at Kiel University (IFM-GEOMAR), Düsternbrooker Weg 20, 24105 Kiel, Germany \\ ${ }^{2}$ Present address: University of Southern California, Department of Biological Sciences, 3616 Trousdale Parkway, AHF 301, \\ Los Angeles, California 90089-0371, USA \\ ${ }^{3}$ Present address: University of Salzburg, Department of Organismic Biology, Hellbrunner Str. 34, 5020 Salzburg, Austria
}

\begin{abstract}
Benthic mixotrophic nanoflagellates (MNF) were studied in coastal sediments in Kiel Fjord, western Baltic Sea. Three types of surface sediment of different grain size were investigated, each along a vertical gradient within the first centimeter depth. A tracer experiment using fluorescently labeled bacteria (FLB) was conducted to identify MNF and quantify their contribution to total bacterivory in different sediment types and depths. MNF abundances and their phagotrophic activity did not vary significantly with sediment depth and grain size. Overall, mixotrophs contributed less to total nanoflagellates in sediments from Kiel Fjord (max. $2 \%$ ) than those recorded from comparable pelagic systems, contributing a higher percentage to total phytoflagellates than to the total bacterivores ( 5 to 10 vs. 2 to $5 \%$, respectively). Potential reasons for these findings could be extensive niche segregation for bacterial grazers, osmotrophic feeding strategies in sediments due to high bacterial abundances and/or rarely limiting nutrient conditions.
\end{abstract}

KEY WORDS: Mixotrophy $\cdot$ Mixotrophic nanoflagellates $\cdot$ Coastal sediment $\cdot$ Benthic microbial ecology $\cdot$ Benthic protists

\section{INTRODUCTION}

The term mixotrophy refers to the ability of organisms to combine heterotrophic and autotrophic modes of nutrition and is primarily used to describe protists that are both phototrophic and phagotrophic (Sanders 1991, Jones 1994). Mixotrophy has been observed in many planktonic protists, including phytoflagellates, ciliates and sarcodines, and has been recorded from eutrophic, mesotrophic, and oligotrophic waters ranging from freshwater ponds to the open ocean (Sanders 1991, Riemann et al. 1995, Stoecker 1998).

The relative contribution of phagotrophy and autotrophy to a species' total energy budget varies among different phytoplankton. The types of mixotrophy reported range along a gradient from nearly pure phototrophy to nearly pure heterotrophy (Jones 1994). In addition, changes in environmental parameters such as light level, nutrient concentration and prey abundance may cause shifts within a species in the relative importance of photosynthesis and phagotrophy (Nygaard \& Tobiesen 1993, Jones 1997, Holen 1999). Therefore, a taxonomic characterization of the microbial community alone does not provide information concerning phagotrophic activity of mixotrophic algae because this activity can be induced or suppressed by a variety of conditions. The identification of mixotrophic algae in natural environments requires the experimental evidence of particle feeding (Sanders et al. 2000). Fluorescently labeled bacteria (FLB) are commonly used to identify mixotrophs in natural planktonic environments and to estimate the effects of their grazing (bacterivory) within the community (e.g. Berninger et al. 1992, Arenovski et al. 1995, Sanders et al. 2000).

Mixotrophic nanoflagellates (MNF) can play a major role as primary producers and as phagotrophs in marine and freshwater ecosystems, although their abundances are highly variable on temporal and spatial scales. MNF were found to contribute up to $50 \%$ to the total phototrophic nanoplankton in different marine and freshwater 
habitats and to account for up to $79 \%$ of the total bacterivory as phagotrophs (Sanders et al. 1989, Berninger et al. 1992, Arenovski et al. 1995, Sanders et al. 2000). Mixotrophic phytoflagellates include chrysophytes, dinoflagellates, prymnesiophytes and cryptophytes. Numerous planktonic studies have described their occurrence, their physiological peculiarities, their contribution to nutrient recycling and their function within microbial food webs (e.g. Sanders et al. 1990, Jones 2000, Bergstrom et al. 2003, Pålsson \& Granéli 2004).

Compared to planktonic habitats, the ecological role of benthic protists is poorly investigated (Hondevelt et al. 1995, Wickham et al. 2000). There are no records of the occurrence or the ecological effect of mixotrophs in benthic ecosystems such as sediments. Tracer experiments with FLB have been adapted to measure grazing rates of benthic protists in sediments, but these studies did not examine bacterivorous mixotrophs (Hondevelt et al. 1995, Starink et al. 1996a). Experimental investigations of benthic protists and their ecological function have been hampered by methodological difficulties, such as the quantitative extraction of the organisms from their habitat (Wickham et al. 2000) and steep vertical gradients of light, oxygen and redox potential that require sampling on a very fine spatial scale (Kühl et al. 1994). The euphotic zone in sediments ranges in depth from a few tenths of a millimeter to several centimeters (depending on sediment grain size), since intense absorption and multiple scattering of light result in a high light attenuation (Kühl \& Jørgensen 1994). Vertical gradients of environmental factors as well as physical properties of sediments, such as grain size, interstitial space and water, influence microbial community structure (e.g. Berninger \& Epstein 1995, Starink et al. 1996b). Changes in environmental parameters were shown to influence mixotrophic feeding behavior in planktonic mixotrophs (see above); therefore, vertical gradients and physical sediment properties could also influence abundances and/or the feeding behavior of benthic MNF.

The present study provides the first records of the occurrence, abundances and phagotrophic activity of bacterivorous MNF in coastal sediments. MNF were investigated in Kiel Fjord in the western Baltic Sea. Three different sediment types with different grain sizes were sampled along a vertical gradient within the first $\mathrm{cm}$ of surface sediment. An FLB grazing experiment was conducted in the laboratory with natural communities of all sediment types in order to investigate whether mixotrophy exists as nutritional strategy among sediment nanoflagellates. Abundances and contributions of MNF to phototrophic and heterotrophic nanoflagellates as well as taxonomic community structure were assessed and compared along the vertical gradients and across different sediment structures.

\section{MATERIALS AND METHODS}

Experimental design and sampling procedure. Experiments were conducted in September/October 2001 and July 2002 with sediment from Falckenstein Beach, Kiel Fjord, western Baltic Sea $\left(10^{\circ} 11^{\prime} 40^{\prime \prime}\right.$ E, $54^{\circ} 24^{\prime} 23^{\prime \prime} N$ ). Sediment samples were taken from 3 different sediment types along a horizontal gradient of Falckenstein Beach (coarse, medium and fine grained sediment). The different sampling sites were located 2 , 5 and $10 \mathrm{~m}$ in the direction below the mean high-water level, at water depths of $0.2,0.3$ and $0.4 \mathrm{~m}$, respectively, and are henceforth called Stns 1, 2 and 3. Due to its relatively small size, the western Baltic Sea exhibits almost no tides (tide-related diurnal water-level amplitude below $15 \mathrm{~cm}$ ) (Lass \& Magaard 1995). However, this amplitude can be exceeded by wind-driven changes in water level. Stn 1 lies within an area which can be above the water level under certain wind conditions, whereas the other 2 sampling sites are submerged at all times.

In September/October 2001, sediment samples were taken only from Stn 1 for the FLB grazing experiment, whereas in July 2002 all 3 stations were sampled for the grazing experiment and for sediment analyses. Sediment was collected using acrylic corers $(2 \mathrm{~mm}$ wall thickness and $20 \mathrm{~cm}$ in length, with an inner diameter of $2.5 \mathrm{~cm}$ ). Four replicate sampling locations were randomly chosen from 20 patches along the beach to account for the heterogeneity of the sediment. Within each patch and station, sediment was collected for the FLB grazing experiment (4 to 6 cores, see below), and in July 2002 also for oxygen profiles and sieving analysis. For sieving analysis, sediment was pooled over the first $\mathrm{cm}$ of surface sediment. For oxygen profiles, sediment cubes $(12.5 \mathrm{~cm} \times 8.5 \mathrm{~cm} \times$ $10 \mathrm{~cm}$ ) were cut out of the sediment and transferred undisturbed into acrylic chambers, maintaining the vertical structure. All sediment samples were processed in the laboratory where the FLB grazing experiment was conducted.

FLB preparation. FLB were prepared using bacteria from freshly enriched sediment in order to provide natural prey organisms for the MNF. Sediment was collected from the experimental sampling site $1 \mathrm{wk}$ before conducting the experiment, diluted $(1: 20)$ with sterile filtered seawater $(0.2 \mu \mathrm{m}$ filtered, FSW), and bacteria isolated by shaking the suspension and filtering the supernatant through a $0.8 \mu \mathrm{m}$ membrane filter (MF Millipore, mixed cellulose esters, $47 \mathrm{~mm}$ ). Bacteria were enriched with trypticase soy broth (TSB) and incubated for $3 \mathrm{~d}$ on a shaking table at room temperature $\left(20^{\circ} \mathrm{C}\right)$. Bacteria were then stained with $2 \mathrm{mg} 5$ (4,6-dichlorotriazin-2-yl)aminofluorescein (DTAF) in accordance with Sherr \& Sherr (1993). The bacterial 
suspension was sonicated after addition of DTAF (B. Braun Biotech International Standard 5T, $3 \times 30 \mathrm{~s}$ at $30 \mathrm{~W}$ power-level) and vortexed every $30 \mathrm{~min}$ during the staining process to assure even distribution and thorough mixing of bacteria and dye. Stained bacterial pellets were resuspended in FSW and $1 \mathrm{ml}$ aliquots were frozen at $-20^{\circ} \mathrm{C}$ and thawed directly before use in an experiment.

Experimental setup and sample processing. In the laboratory, sediment cores were extruded and $3 \mathrm{~mm}$ thick sediment slices of different layers $(0-3,3-6$ and 6-9 $\mathrm{mm}$ ) were transferred onto tissue culture plates (Renner, Tissue Culture Test Plates, 6 wells per plate, well radius $=3.45 \mathrm{~cm}$, well volume $=15.53 \mathrm{~cm}^{3}$ ) with $2 \mathrm{ml}$ of sterile FSW. From 1 additional core, bacterial abundances were calculated for each station, and FLB numbers approximating $25 \%$ of the natural bacterial abundances (Sherr \& Sherr 1993) were added to the slurries. In September/October 2001, sediment samples were set up in parallel light and dark incubations, while in July 2002 all samples were incubated in the dark. Sampling was necessarily destructive; therefore, 2 separate samples were inoculated per station, treatment and replicate for the 2 sampling events $\left(t_{0}\right.$ and $\left.t_{16}\right)$ in the FLB experiment. After FLB addition, $t_{0}$ samples were fixed with ice-cold glutaraldehyde at a final concentration of $1.5 \%$. The remaining live samples containing FLB were incubated in a climate chamber for $16 \mathrm{~h}$ at $18^{\circ} \mathrm{C}$. Dark incubations were covered in aluminum foil and light incubations were subject to a light:dark cycle of 16:8 h at a light intensity of $60 \mu \mathrm{E} \mathrm{m} \mathrm{m}^{-2} \mathrm{~s}^{-2}$ (measured with LI-COR LI-189). After $16 \mathrm{~h}, t_{16}$ samples were fixed and all samples stored at $4^{\circ} \mathrm{C}$ in the dark until further processing (within $24 \mathrm{~h}$ ).

Fixed sediment samples were transferred into a $300 \mathrm{ml}$ polystyrene cell culture flask, diluted with FSW to a total volume of $150 \mathrm{ml}$ and the suspension thoroughly shaken. Of the supernatant, $20 \mathrm{ml}$ were fixed with glutaraldehyde at a final concentration of $1.5 \%$. Depending on species abundances and organic material, 0.5 to $5 \mathrm{ml}$ of this subsample were collected on a $0.2 \mu \mathrm{m}$ polycarbonate filter (Nucleopore) and stained with DAPI (4', 6-diamidino-2-phenylindole) for $5 \mathrm{~min}$ at a final concentration of $5 \mu \mathrm{g} \mathrm{ml}^{-1}$, to visualize the DNA of bacteria and protists (Porter \& Feig 1980, Sherr \& Sherr 1993). Filters and a drop of immersion oil were sealed between a slide and cover slip with paraffin wax and stored at $-20^{\circ} \mathrm{C}$ until microscopical analysis.

Sediment analysis, July 2002. Oxygen profiles were measured in sediment in the acrylic glass chambers at a vertical resolution of $100 \mu \mathrm{m}$ in a climate chamber at $18^{\circ} \mathrm{C}$ and a light intensity of $60 \mu \mathrm{E} \mathrm{m} \mathrm{m}^{-2} \mathrm{~s}^{-1}$, employing oxygen microelectrodes, according to the description in Revsbech \& Jørgensen (1986). Electrodes were calibrated to $100 \%$ just above the sediment surface. For the sieving analysis, sediment samples were dried overnight at $70^{\circ} \mathrm{C}$ until their weight was constant. Sediment from every station was weighed, sieved through different mesh sizes $(0.063,0.5,1,2$ and $3.5 \mathrm{~mm})$ and size fractions weighed to calculate weight proportions of different grain sizes.

Enumeration. In all experiments, flagellates, diatoms, cyanobacteria, bacteria and FLB were counted on the filter preparations using an epifluorescence microscope (Leica/Leitz DMRB) at 1000× magnification. Flagellates, diatoms and FLB were enumerated using a blue filter set (450 to $490 \mathrm{~nm}$ excitation, $>515 \mathrm{~nm}$ emission); for bacteria a UV filter set (340 to $380 \mathrm{~nm}$ excitation, >420 nm emission, Leica/Leitz filter set A) was used. Flagellates and diatoms were counted in 60 to 80 fields of view (50 to $>200$ cells per group counted per filter), bacteria and FLB in 12 fields of view (>200 cells counted per filter). Phototrophic and heterotrophic nanoflagellates (PNF and HNF) were differentiated by the presence/absence of chlorophyll autofluorescence. MNF were defined as autofluorescent cells containing one or more ingested FLB (visible in the flagellates as green fluorescing rods and cocci). However, it was not possible to determine exact numbers of ingested FLB, since multiple FLB were sometimes visible only as green fluorescing clumps within the flagellates. In July 2002, sediment samples were additionally analyzed to classify flagellates into major systematic groups, using a live counting technique (Gasol 1993, Dietrich \& Arndt 2000). Diluted natural sediment subsamples $(1: 10)$ were thoroughly mixed and 3 aliquots of 5 to $20 \mu$ were counted per station and depth on a slide under an upright phase contrast microscope at $400 \times$ magnification (Leitz Dialux 20). For the identification of different taxonomic groups, guides by Larsen \& Patterson (1990), Patterson \& Larsen (1991), and Tomas (1997) were used.

Statistical analysis. Differences in MNF abundances in light and dark incubations of experiments in September/October 2001 were tested with a 1factor ANOVA. Differences in components of the microbial community at different stations and depths were tested with a 2-factor ANOVA (station $\times$ depth) on absolute abundances of HNF, PNF, MNF, diatoms, cyanobacteria and bacteria, as well as on relative abundances of MNF and different taxonomic groups. Normal distribution and homogeneity of variances were tested with a chi-square test and with a Bartlett chi-square test, respectively. Post-hoc tests to determine differences in species abundances at particular stations and depths were conducted with Tukey's HSD test. 


\section{RESULTS}

\section{Sediment analysis}

The stations sampled at Falckenstein Beach, Kiel Fjord, western Baltic Sea, in July 2002 clearly differed in sediment structure and grain size, becoming increasingly finer with increasing distance from the shoreline (Fig. 1). At Stn 1, oxygen saturation declined from $>100 \%$ at a depth of $3 \mathrm{~mm}$ to $7 \%$ at $10 \mathrm{~mm}$ depth (Fig. 2). At Stns 2 and 3, oxygen was depleted below 5 and $4.5 \mathrm{~mm}$ depth, respectively. At Stn 2, oxygen saturation declined steeply below a surface maximum of $>100 \%$, whereas at Stn 3 the sediment was completely saturated with oxygen in the first $2 \mathrm{~mm}$ and then declined to oxygen depletion (Fig. 2).

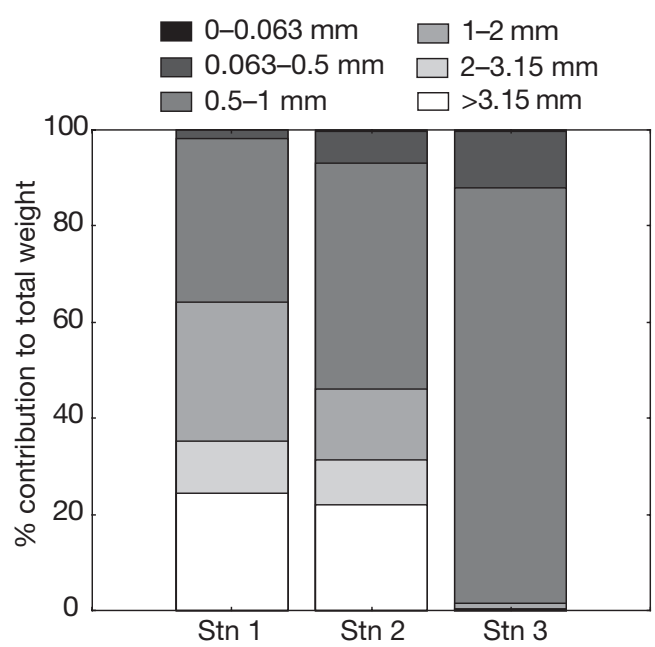

Fig. 1. Weight proportions of different sediment grain size fractions at Stns 1,2 and 3 (the fraction $0-0.063 \mathrm{~mm}$ was $<1 \%$ at all stations). Station numbers correspond to increasing distance from shore and increasing water depth (see 'Materials and methods; Experimental design and sampling procedure')

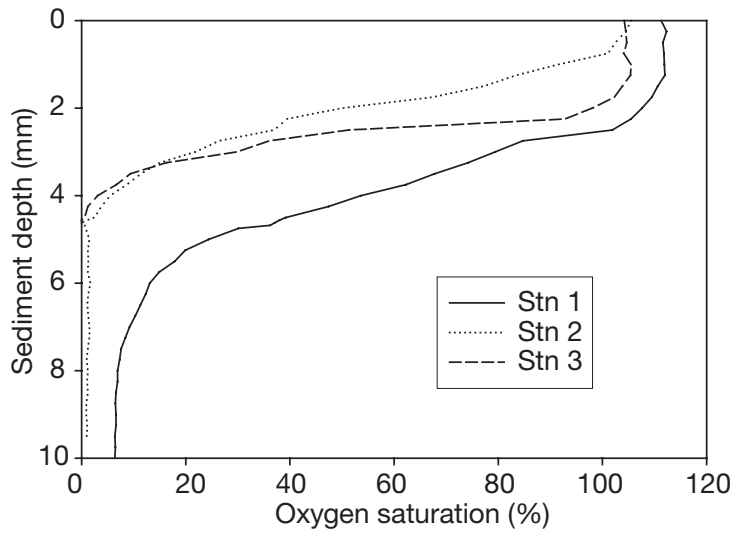

Fig. 2. Oxygen profiles (\% saturation) measured with a spatial resolution of $0.1 \mathrm{~mm}$ in the first $10 \mathrm{~mm}$ of sediment at Stns 1 , 2 and 3 in July 2002
Abundances of organisms and species composition

Abundances

In September/October 2001 (Stn 1), MNF abundances ranged from $4.2 \times 10^{3}$ to $1.7 \times 10^{5} \mathrm{~cm}^{-3}$ of sediment. The number of flagellates identifiable as mixotrophs was significantly higher in the dark compared to light incubations (Fig. 3, Table 1A, p < 0.05). Consequently, the July experiment was also conducted in the dark for all sediment types and depths. In July, all nanoflagellate assemblages at all stations and sediment depths were clearly dominated by HNF, which comprised $\leq 80 \%$ of the nanoflagellate assemblage (Fig. 4). PNF comprised $\leq 20 \%$ of the nanoflagellates, and MNF contributed the remaining 1 to $2 \%$ (Fig. 4). Abundances of HNF, PNF, MNF, diatoms, cyanobacteria and bacteria all increased significantly from Stns 1 to 3 (Fig. 5, p < 0.001), but there was no significant interaction of station and sediment depth effects (Tukey's HSD test). Within each station, change in abundance with depth was not significant for any of these groups (Fig. 5).

\section{Relative contributions and taxonomic composition}

Overall, MNF comprised 5 to $10 \%$ of the total phytoflagellates (PNF + MNF), while MNF contribution to the total flagellate grazers $(\mathrm{HNF}+\mathrm{MNF})$ ranged from 1 to $3 \%$ at all stations in all layers (Table 2). There were no significant differences of relative MNF contributions across different stations or sediment depth.

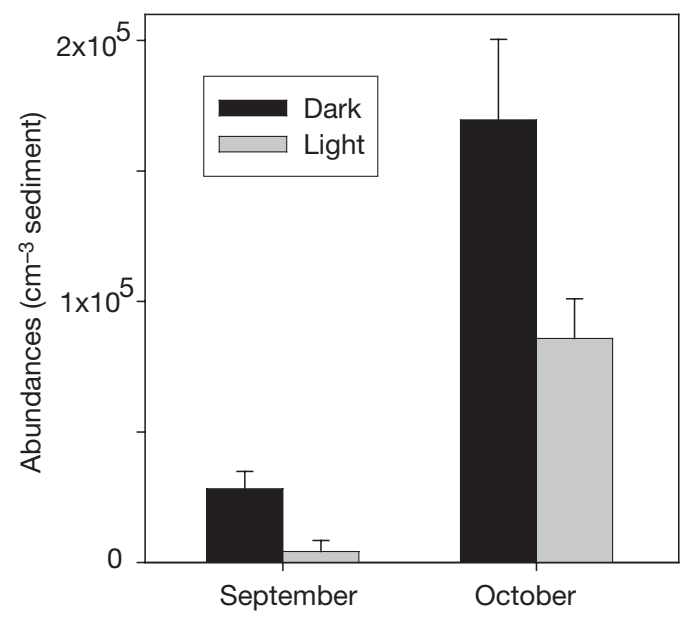

Fig. 3. Absolute abundances (mean \pm SE) of mixotrophic nanoflagellates in light and dark incubations in 2 experiments in September and October 2001. Differences between light and dark incubations were significant 
Table 1. (A) A 1-factor ANOVA (light/dark) on absolute abundances of mixotrophic nanoflagellates (MNF) in 2 experiments in September and October 2001. (B) A 2-factor ANOVA (Stn $\times$ Depth) on relative abundances of different taxonomic groups of the microbial community (Chrys.: Chrysomonadida; Crypt.: Cryptomonadida; Dino.: Dinoflagellata; Eugl.: Euglenida; Undet.: Undetermined; Kinet.: Kinetoplasta; Thau.: Thaumatomastigida; Inc.Sed. : Incertae Sedis; Apu. : Apusomonadida). F-ratios (significance levels in parentheses) for the main factors are given. Degrees of freedom (df) for the effect terms are given in parentheses for each effect, and for the error term in the first row of each analysis. Effects significant at $\mathrm{p}<0.05$ in bold, trends with $\mathrm{p}<0.1$ in italics

\begin{tabular}{|c|c|c|c|c|c|c|c|c|c|}
\hline (A) & \multicolumn{2}{|c|}{ MNF (Sep) } & MNF (Oct) & \multirow[b]{4}{*}{ Eugl. } & \multirow[b]{4}{*}{ Indet. } & \multirow[b]{4}{*}{ Kinet. } & \multirow[b]{4}{*}{ Thau. } & \multirow[b]{4}{*}{ Inc.Sed. } & \multirow[b]{4}{*}{ Apu. } \\
\hline & \multirow{2}{*}{\multicolumn{2}{|c|}{$\begin{array}{c}6 \\
9.335(\mathbf{0 . 0 2})\end{array}$}} & \multirow{2}{*}{$\begin{array}{c}6 \\
5.948(\mathbf{0 . 0 5})\end{array}$} & & & & & & \\
\hline Light/dark (1) & & & & & & & & & \\
\hline (B) & Chrys. & Crypt. & Dino. & & & & & & \\
\hline df & 18 & 18 & 18 & 18 & 18 & 18 & 18 & 18 & 27 \\
\hline Stn $(2)$ & $\begin{array}{l}1.235 \\
(0.315)\end{array}$ & $\begin{array}{c}1.134 \\
(0.344)\end{array}$ & $\begin{array}{c}20.949 \\
(<\mathbf{0 . 0 0 1})\end{array}$ & $\begin{array}{c}0.286 \\
(0.755)\end{array}$ & $\begin{array}{c}1.154 \\
(0.338)\end{array}$ & $\begin{array}{c}1.373 \\
(0.279)\end{array}$ & $\begin{array}{c}12.162 \\
(<\mathbf{0 . 0 0 1})\end{array}$ & $\begin{array}{l}50.024 \\
(<\mathbf{0 . 0 0 1})\end{array}$ & $\begin{array}{c}1.952 \\
(0.171)\end{array}$ \\
\hline Depth (2) & $\begin{array}{c}3.088 \\
(0.070)\end{array}$ & $\begin{array}{l}1.204 \\
(0.323)\end{array}$ & $\begin{array}{c}0.542 \\
0.591)\end{array}$ & $\begin{array}{c}0.765 \\
(0.480)\end{array}$ & $\begin{array}{c}14.174 \\
(<\mathbf{0 . 0 0 1 )}\end{array}$ & $\begin{array}{c}3.205 \\
(0.065)\end{array}$ & $\begin{array}{c}0.622 \\
(0.548)\end{array}$ & $\begin{array}{c}12.800 \\
(<\mathbf{0 . 0 0 1})\end{array}$ & $\begin{array}{r}4.429 \\
(\mathbf{0 . 0 2 7})\end{array}$ \\
\hline $\begin{array}{l}\text { Stn } \times \\
\text { Depth (4) }\end{array}$ & $\begin{array}{c}3.887 \\
(\mathbf{0 . 0 1 9})\end{array}$ & $\begin{array}{c}1.891 \\
(0.156)\end{array}$ & $\begin{array}{c}5.137 \\
(\mathbf{0 . 0 0 6})\end{array}$ & $\begin{array}{c}2.026 \\
(0.134)\end{array}$ & $\begin{array}{c}3.042 \\
(\mathbf{0 . 0 4 4})\end{array}$ & $\begin{array}{c}3.583 \\
(\mathbf{0 . 0 2 6})\end{array}$ & $\begin{array}{c}2.358 \\
(0.092)\end{array}$ & $\begin{array}{c}12.800 \\
(<\mathbf{0 . 0 0 1})\end{array}$ & $\begin{array}{c}1.986 \\
(0.140)\end{array}$ \\
\hline
\end{tabular}

In live counts, flagellates were classified into the following groups: Kinetoplasta, Apusomonadida and Thaumatomastigida (only heterotrophic forms), cryptophytes (mostly phototrophic as well as mixotrophic forms), chrysophytes, dinoflagellates and euglenids (heterotrophic, phototrophic and mixotrophic forms). The taxonomic composition of the protistan assemblage changed with depth at all stations (Fig. 6). However, contributions of groups that include potentially mixotrophic species, such as chrysophytes, cryptophytes and dinoflagellates, did not differ significantly with sediment depth at any station (Table 1B). At Stn 1, purely heterotrophic forms (Thaumatomastigida, Kinetoplasta, Apusomonadida) constituted $>50 \%$ of the flagellate community, while chrysophytes, cryptophytes and dinoflagellates contributed small shares (20 to $30 \%$ ) of total flagellate abundances (Fig. 6). Relative abundances of Thaumatomastigida in the deepest sediment layer of Stn 1 significantly exceeded abundances of all sediment layers at Stns 2 and 3. At Stn 2, chrysophytes and cryptophytes comprised 10 to 20 and 5 to $10 \%$ of the total flagellate community, respectively. There were no significant variations of abundances with depth at Stn 2, except for Kinetoplasta, whose abundances in the inter- mediate sediment layer significantly exceeded those in the deepest sediment layer. At Stn 3, dinoflagellates and cryptophytes constituted $<10 \%$ of the flagellate assemblage at all depths, while chrysophytes increased from $10 \%$ in the surface layer to $>20 \%$ in the intermediate layer, but were absent from the deepest sediment layer (Fig. 6).

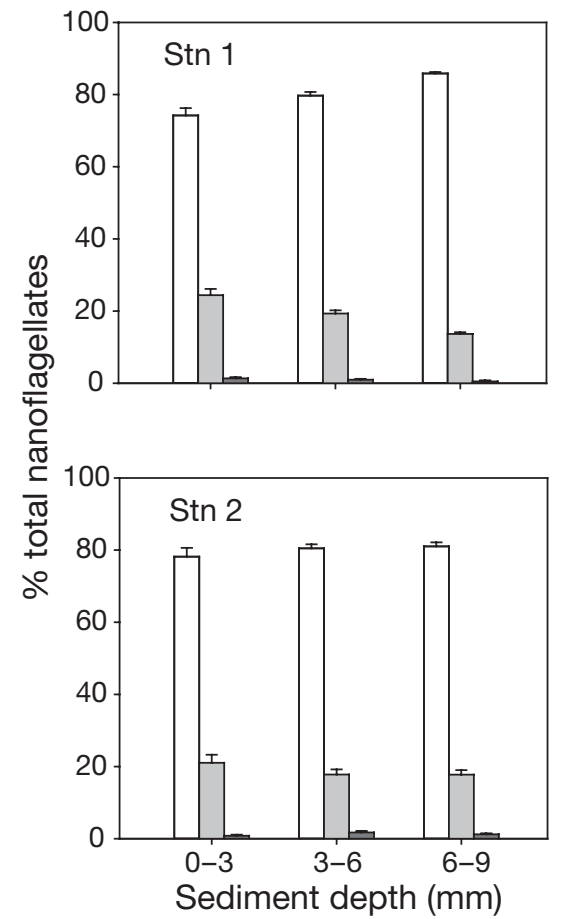

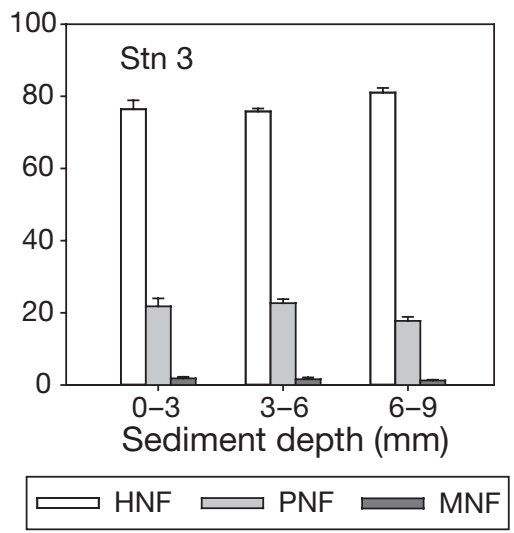

Fig. 4. Relative abundances (mean $\pm \mathrm{SE}$ ) of heterotrophic (HNF), phototrophic (PNF) and mixotrophic (MNF) nanoflagellates as percentage of the total nanoflagellates at Stns 1, 2 and 3 in all sediment layers $(0-3,3-6,6-9 \mathrm{~mm}$ depth) in July 2002 

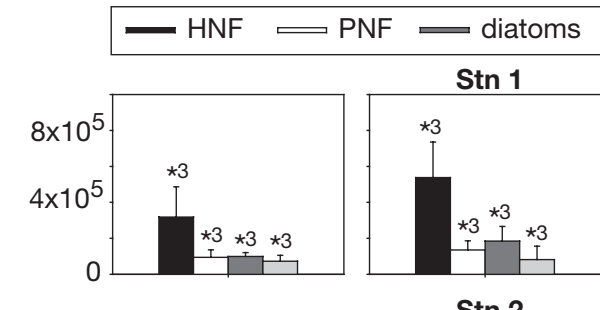

cyanobacteria

Stn 2
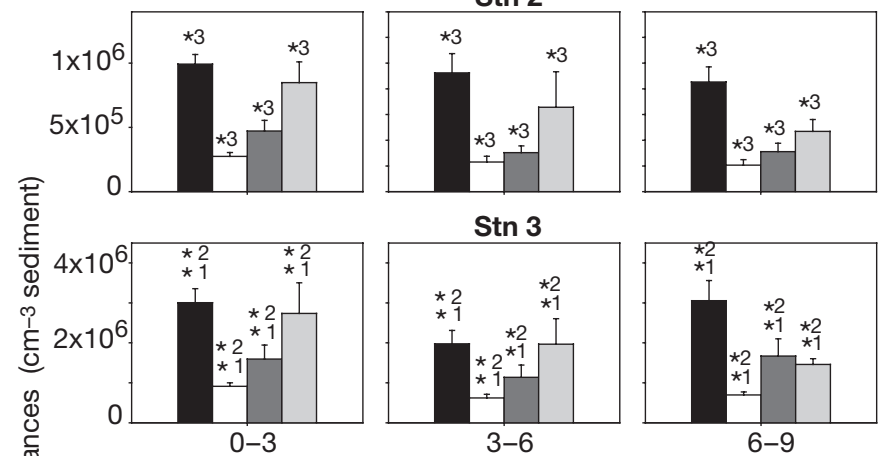

Stn 3
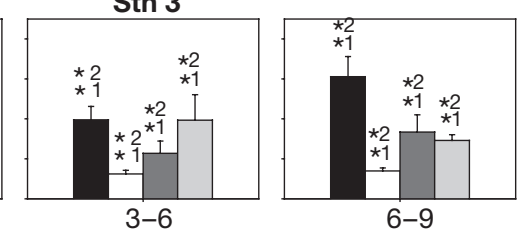

Sediment depth $(\mathrm{mm})$

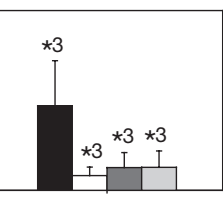

产
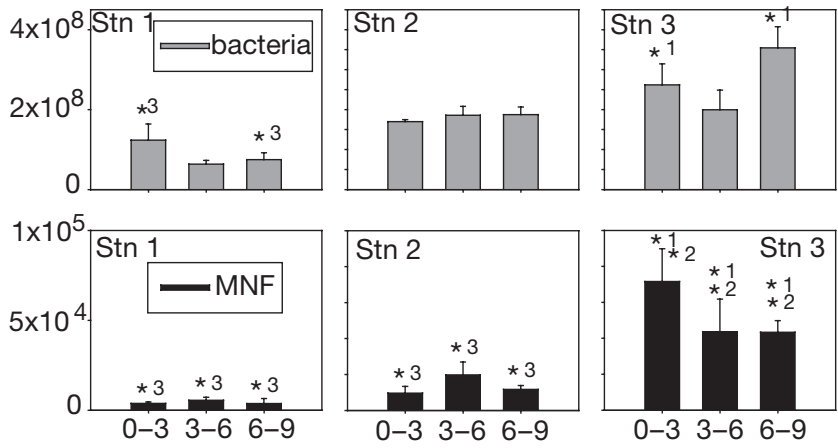

-3 $3-6$ 6-9

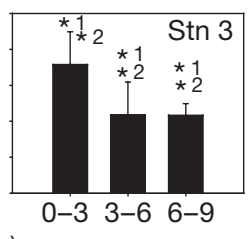

Fig. 5. Absolute abundances (mean $\pm \mathrm{SE}$ ) of heterotrophic nanoflagellates (HNF), phototrophic nanoflagellates (PNF), mixotrophic nanoflagellates (MNF), diatoms, cyanobacteria and bacteria at Stns 1, 2 and 3 in all sediment layers $(0-3,3-6$, 6-9 mm depth) in July 2002. Significant differences between stations are marked with an asterisk and the station number from which the abundances differ

Table 2. Relative abundances (mean $\pm \mathrm{SE}$ ) of mixotrophic nanoflagellates as percentage of the total phototrophic nanoflagellates (PNF) and the total heterotrophic nanoflagel-

lates (grazers) at Stns 1, 2 and 3 in all sediment layers

\begin{tabular}{|cccc|}
\hline \multicolumn{2}{c}{ Sediment depth $(\mathrm{mm})$} & \% total PNF & \% total grazers \\
\hline Stn 1 & $0-3$ & $5.2 \pm 0.9$ & $1.8 \pm 0.4$ \\
& $3-6$ & $4.7 \pm 0.9$ & $1.2 \pm 0.3$ \\
& $6-9$ & $3.5 \pm 2.1$ & $0.6 \pm 0.3$ \\
Stn 2 & $0-3$ & $3.3 \pm 1.3$ & $1.0 \pm 0.4$ \\
& $3-6$ & $9.1 \pm 2.5$ & $2.1 \pm 0.5$ \\
& $6-9$ & $6.4 \pm 1.6$ & $1.4 \pm 0.3$ \\
Stn 3 & $0-3$ & $7.4 \pm 1.4$ & $2.4 \pm 0.6$ \\
& $3-6$ & $6.6 \pm 2.3$ & $2.0 \pm 0.6$ \\
& $6-9$ & $6.3 \pm 0.7$ & $1.5 \pm 0.3$ \\
\hline
\end{tabular}
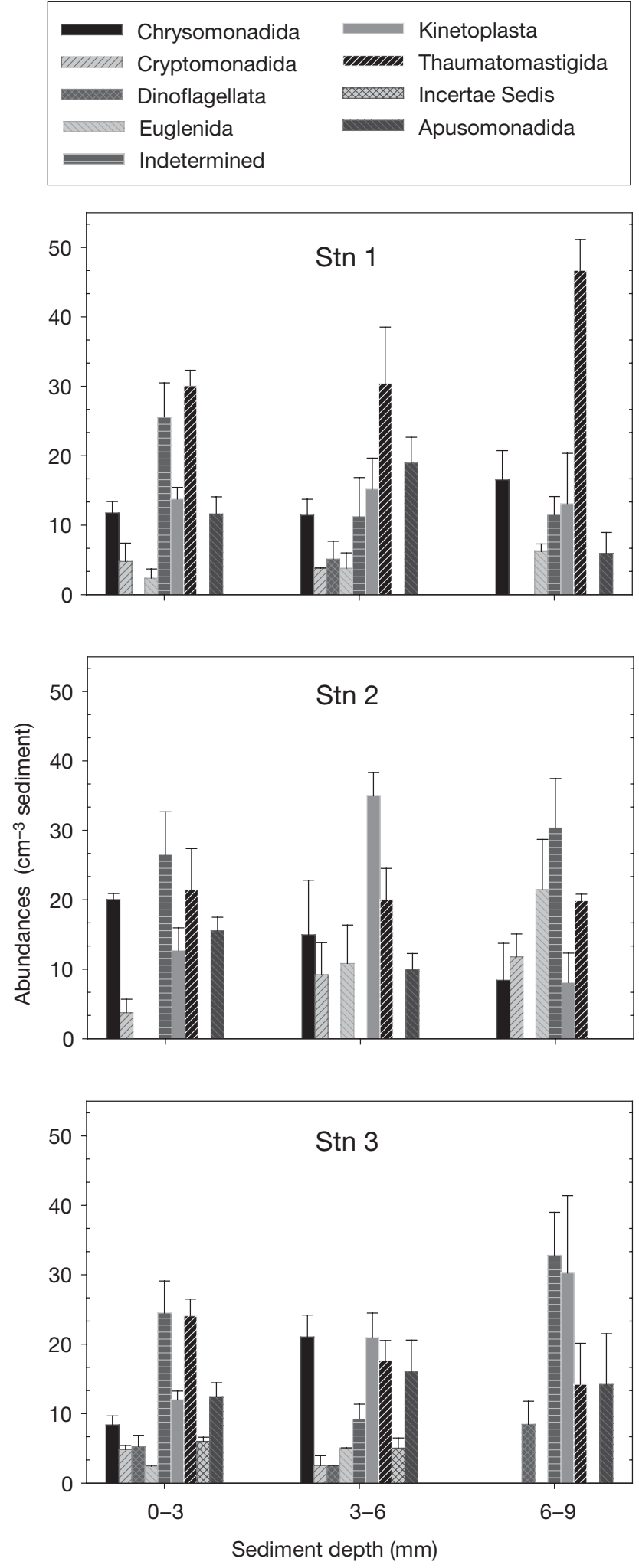

Fig. 6. Taxonomic composition at Stns 1,2 and 3 in all sediment layers $(0-3,3-6,6-9 \mathrm{~mm}$ depth) in July 2002. Relative abundances (mean $\pm \mathrm{SE}$ ) of different taxonomic groups are calculated as a percentage of the total flagellates 


\section{DISCUSSION}

MNF were observed in all different sediment types and depths investigated in the present study. However, they comprised only a small percentage $(\leq 2 \%)$ of the total nanoflagellates and of bacterial grazers (2 to $5 \%$ ). Up to $10 \%$ of the total phytoflagellates were mixotrophic, but considering other autotrophs such as diatoms or cyanobacteria, MNF most likely contributed little to overall primary production.

Relative abundances of phagotrophically active mixotrophs did not vary significantly across different stations or with sediment depth. Potential limitation of photosynthesis in deeper sediment layers and/or in finer-grained sediments did not influence abundances or phagotrophic feeding activity in mixotrophs. Chrysophytes, which are commonly known to exhibit mixotrophy in planktonic systems (e.g. Boraas et al. 1988, Sanders \& Porter 1988), were the most abundant of the potentially mixotrophic taxonomic groups (up to $20 \%$ of the total nanoflagellates), and most likely constituted the majority of mixotrophs observed in the present study.

Absolute abundances of all eukaryotes increased from Stns 1 to 3. This could be due either to water movement directly behind the shoreline (resuspension of organisms in the water column or migration into deeper sediment layers) or to sediment characteristics, such as sediment grain size and interstitial water contents that influence microbial community structure (Alongi 1986, Gasol 1993). Sediments at different stations differed in grain size and oxygen saturation. Light propagation in sediments is a key parameter for microbenthic photosynthesis that varies with grain size, with the light attenuation coefficient $K(K=$ $-\mathrm{d} \ln E / \mathrm{d} z$, where $z=$ depth and $E=$ irradiance) decreasing substantially from coarse to fine-grained sediments (Kühl et al. 1994). Oxygen saturation cannot be directly related to light propagation in sediments. However, the greater oxygen depletion with depth in the more fine-grained sediment at Stn 3 compared to the coarser sediment at Stn 1 (Fig. 2) does suggest a potential for more light limitation of photosynthesis in finer sediments.

A large number of studies demonstrated experimentally that a range of environmental factors (such as light, nutrients, water temperature, prey abundances) can affect the abundance of mixotrophs. However, none of these factors appear to consistently promote or repress the occurrence and activity of mixotrophs. Light limitation, for instance, has been shown to have disparate effects on planktonic mixotrophs, depending on species identity and on environmental factors such as nutrient availability and prey abundances. Some laboratory studies demonstrated increasing feeding rates in bacterivorous MNF under light limitation (Veen 1991, Holen 1999), while others revealed lower ingestion rates under low light conditions or darkness (Caron et al. 1993, Jones \& Rees 1994) or no effects of light at all (Andersson et al. 1989, Sanders et al. 1990). In field studies of plankton, MNF abundances were related to low light intensities in some cases (Bird \& Kalff 1986, Pålsson \& Granéli 2004), while in others MNF abundances seemed to be more dependent on other factors, such as water temperature (Bird \& Kalff 1987) and nutrient availability (Nygaard \& Tobiesen 1993, Arenovski et al. 1995). Prey abundances and abundances of purely heterotrophic or phototrophic competitors have also been shown to influence MNF abundances and feeding behavior (Rothhaupt 1996, Sanders et al. 2000). In this context, the type of mixotrophy (primary/obligate phototroph or heterotroph and/or particular nutrient requirements; see Jones 1997) seems to govern the response of mixotrophic species to those environmental factors. It has been shown that different kinds of feeding behavior can occur within the same genus of mixotrophs (e.g. Dinobryon, Ochromonas), while similar types of behavior can be shown in species that are taxonomically not related (Jones 1997). These aspects complicate the analysis of factors that can influence the mixotrophic assemblage and make it difficult to predict where and when mixotrophy will be an important ecosystem process.

In this study, relative contributions of MNF to phytoflagellates or bacterivorous nanoflagellates in all sediment types and depths were much lower than previously reported for planktonic systems (e.g. Berninger et al. 1992, Arenovski et al. 1995). We suggest that at least 3 factors contributed to the low occurrence of mixotrophs in the coastal sediments examined in this study. (1) Phagotrophy instead of mixotrophy: Phagotrophic protists in sediment show a variety of specialized organelle structures for feeding (Patterson et al. 1989), and have a wide range of feeding strategies to capture the variety of interstitial and attached bacteria (Starink et al. 1994). Specialized phagotrophic feeding strategies may give heterotrophs a greater competitive advantage in sediments compared to the plankton. (2) Osmotrophy instead of mixotrophy: Many phytoplankters can take up dissolved organic carbon (Lewitus \& Kana 1995), and benthic diatoms can use dissolved free amino acids or organic material osmotrophically under light limitation (Admiraal et al. 1987). Since sediments yield high concentrations of macromolecules and dissolved organic substances, osmotrophy may be a more efficient mechanism of energy or nutrient uptake than phagotrophy for potential mixotrophs in these environments. (3) System-specific aspects - spatial scales: Organisms in sediments are able to escape 
unfavorable environmental conditions on spatial scales from millimeters to centimeters. Protists in the water column, however, have to overcome much longer distances along vertical gradients of environmental factors $(1$ to $100 \mathrm{~m}$ ) and cannot respond to unfavorable conditions of light or dissolved nutrient availability as easily as protists in sediments. Therefore, mixotrophic feeding strategies might be essential for survival in pelagic environments, but play a minor role in coastal sediments.

The present study provides the first data on the occurrence and abundances of MNF in coastal sediments. Our finding that MNF were present, but not numerous, in all of our experiments indicates that mixotrophy, at least as phagotrophic supplementation of phototrophy, might not be as important a nutritional strategy in sediments as it is in planktonic environments. Investigations of mixotrophs in different sediments from contrasting systems of different geographical sites would help to ascertain whether the patterns observed in this study can be generalized to coastal sediments or are unique to the sediments investigated in the western Baltic Sea. Furthermore, natural sediment communities should be investigated under controlled experimental conditions in the laboratory in order to clearly evaluate the importance of light availability and other environmental factors influencing the trophic mode of benthic mixotrophs.

Acknowledgements. We thank K. Stumm from the Alfred Wegener Institute for Polar and Marine Research for her help collecting the samples, D. Dietrich for her help with the live counting technique, H. Hillebrand and U. Sommer from the Leibniz Institute of Marine Sciences at Kiel University (IFM-GEOMAR) for helpful discussions, and the DFG (Deutsche Forschungsgemeinschaft, BE 2279/2) and the DAAD (Deutscher Akademischer Austauschdienst) for their financial support.

\section{LITERATURE CITED}

Admiraal W, Riaux-Gobin C, Laane RW (1987) Interactions of ammonium, nitrate, and D- and L-amino acids in the nitrogen assimilation of two species of estuarine benthic diatoms. Mar Ecol Prog Ser 40:267-273

Alongi DM (1986) Quantitative estimates of benthic protozoa in tropical marine systems using silica gel: a comparison of methods. Estuar Coast Shelf Sci 23:443-450

Andersson A, Falk S, Samuelsson G, Hagström A (1989) Nutritional characteristics of a mixotrophic nanoflagellate, Ochromonas sp. Microb Ecol 17:251-262

Arenovski AL, Lim EL, Caron DA (1995) Mixotrophic nanoplankton in oligotrophic surface waters of the Sargasso Sea may employ phagotrophy to obtain major nutrients. J Plankton Res 17:801-820

Bergstrom AK, Jansson M, Drakare S, Blomqvist P (2003) Occurrence of mixotrophic flagellates in relation to bacterioplankton production, light regime and availability of inorganic nutrients in unproductive lakes with differing humic contents. Freshw Biol 48:868-877
Berninger UG, Epstein SS (1995) Vertical distribution of benthic ciliates in response to the oxygen concentration in an intertidal North Sea sediment. Aquat Microb Ecol 9: $229-236$

Berninger UG, Caron DA, Sanders RW (1992) Mixotrophic algae in three ice-covered lakes of the Pocono Mountains, U.S.A. Freshw Biol 28:263-272

Bird DF, Kalff J (1986) Bacterial grazing by planktonic lake algae. Science 231:493-494

Bird DF, Kalff J (1987) Algal phagotrophy: regulating factors and importance relative to photosynthesis in Dinobryon (Chrysophyceae). Limnol. Oceanogr. 32:277-284

Boraas ME, Estep KW, Johnson PW, Sieburth JM (1988) Phagotrophic phototrophs: the ecological significance of mixotrophy. J Protozool 35:249-252

Caron DA, Sanders RW, Lim EL, Marrase C, Amaral LE, Whitney S, Aoki RB, Porter KG (1993) Light-dependent phagotrophy in the freshwater mixotrophic chrysophyte Dinobryon cylindricum. Microb Ecol 25:93-111

Dietrich D, Arndt H (2000) Biomass partitioning of benthic microbes in a Baltic inlet: relationships between bacteria, algae, heterotrophic flagellates and ciliates. Mar Biol 136:309-322

Gasol JM (1993) Benthic flagellates and ciliates in fine freshwater sediments: calibration of a live counting procedure and estimation of their abundances. Microb Ecol 25: 247-262

Holen DA (1999) Effects of prey abundance and light intensity on the mixotrophic chrysophyte Poterioochromonas malhamensis from a mesotrophic lake. Freshw Biol 42: 445-455

Hondevelt BJM, Nieuwland G, Van Duyl FC, Bak RPM (1995) Impact of nanoflagellate bacterivory of benthic bacterial production in the North Sea. Netherlands J Sea Res $34: 275-287$

Jones HLJ (1997) A classification of mixotrophic protists based on their behaviour. Freshw Biol 37:35-43

Jones RI (1994) Mixotrophy in planktonic protists as a spectrum of nutritional strategies. Mar Microb Food Webs 8: 87-96

Jones RI (2000) Mixotrophy in planktonic protists: an overview. Freshw Biol 45:219-226

Jones RI, Rees S (1994) Characteristics of particle uptake by the phagotrophic phytoflagellate, Dinobryon divergens. Mar Microb Food Webs 8:97-110

Kühl M, Jørgensen BB (1994) The light field of microbenthic communities: radiance distribution and microscale optics of sandy coastal sediments. Limnol Oceanogr 39: 1368-1398

Kühl M, Lassen C, Jorgensen BB (1994) Light penetration and light intensity in sandy marine sediments measured with irradiance and scalar irradiance fiber-optic microprobes. Mar Ecol Prog Ser 105:139-148

Larsen J, Patterson DL (1990) Some flagellates (Protista) from tropical marine sediments. J Nat Hist 24:801-937

Lass HU, Magaard L (1995) Wasserstandsschwankungen und Seegang. In: Rheinheimer G (ed) Meereskunde der Ostsee. Springer-Verlag, Berlin, p 68-74

Lewitus AJ, Kana TM (1995) Light respiration in six estuarine phytoplankton species: contrasts under photoautotrophic and mixotrophic growth conditions. J Phycol 31:754-761

Nygaard K, Tobiesen A (1993) Bacterivory in algae: a survival strategy during nutrient limitation. Limnol Oceanogr 38:273-279

Pålsson C, Granéli W (2004) Nutrient limitation of autotrophic and mixotrophic phytoplankton in a temperate and tropical humic lake gradient. J Plankton Res 26:1005-1014 
Patterson DJ, Larsen J (1991) The biology of free-living heterotrophic flagellates, Vol 45. Clarendon Press, Oxford

Patterson DJ, Larsen J, Corliss JO (1989) The ecology of heterotrophic flagellates and ciliates living in marine sediments. In: Corliss JC, Patterson DJ (eds) Progress in protistology, Vol 3. Biopress, Bristol, p 185-278

Porter KG, Feig YS (1980) The use of DAPI for identifying and counting aquatic microflora. Limnol Oceanogr 25:943-948

Revsbech NP, Jørgensen BB (1986) Microelectrodes: their use in microbial ecology. Adv Microb Ecol 9:293-352

Riemann B, Havskum H, Thingstad F, Bernard C (1995) The role of mixotrophy in pelagic environments. In: Joint I (ed) Molecular ecology of aquatic microbes. Springer-Verlag, Berlin, p 87-114

Rothhaupt KO (1996) Laboratory experiments with a mixotrophic chrysophyte and obligately phagotrophic and phototrophic competitors. Ecology 77:716-724

Sanders RW (1991) Mixotrophic protists in marine and freshwater ecosystems. J Protozool 38:76-81

Sanders RW, Porter KG (1988) Phagotrophic phytoflagellates. Adv Microb Ecol 10:167-192

Sanders RW, Porter KG, Bennett SJ, DeBiase AE (1989) Seasonal patterns of bacterivory by flagellates, ciliates, rotifers, and cladocerans in a freshwater planktonic community. Limnol Oceanogr 34:673-687

Sanders RW, Porter KG, Caron DA (1990) Relationship between phototrophy and phagotrophy in the mixotrophic chrysophyte Poterioochromonas malhamensis. Microb Ecol 19:97-109

Sanders RW, Berninger UG, Lim EL, Kemp PF, Caron DA (2000) Heterotrophic and mixotrophic nanoplankton pre-

Editorial responsibility: Robert Sanders, Philadelphia, Pennsylvania, USA dation on picoplankton in the Sargasso Sea and on Georges Bank. Mar Ecol Prog Ser 192:103-118

Sherr BF, Sherr EB (1993) Protistan grazing rates via uptake of fluorescently labeled prey. In: Kemp PF, Sherr BF, Sherr EB, Cole JJ (eds) Handbook of methods in aquatic microbial ecology. CRC Press, Boca Raton, FL, p 695-701

Starink M, Krylova IN, Bär-Gilissen MJ, Bak RPM, Cappenberg TE (1994) Rates of benthic protozoan grazing on free and attached sediment bacteria measured with fluorescently stained sediment. Appl Environ Microbiol 60: 2259-2264

Starink M, Bär-Gilissen MJ, Bak RPM, Cappenberg TE (1996a) Bacterivory by heterotrophic nanoflagellates and bacterial production in sediments of a freshwater littoral system. Limnol Oceanogr 41:62-69

Starink M, Bär-Gilissen MJ, Bak RPM, Cappenberg TE (1996b) Seasonal and spatial variations in heterotrophic nanoflagellate and bacteria abundances in sediments of a freshwater littoral zone. Limnol Oceanogr 41:234-242

Stoecker DK (1998) Conceptual models of mixotrophy in planktonic protists and some ecological and evolutionary implications. Eur J Protistol 34:281-290

Tomas CR (1997) Identifying marine phytoplankton. Academic Press, London

Veen A (1991) Ecophysiological studies on the phagotrophic phytoflagellate Dinobryon divergens Imhof. PhD thesis, University of Amsterdam

Wickham S, Gieseke A, Berninger UG (2000) Benthic ciliate identification and enumeration: an improved methodology and its application. Aquat Microb Ecol 22:79-91

Submitted: March 13, 2006; Accepted: September 1, 2006 Proofs received from author(s): October 17, 2006 